\title{
The Military Expansion into the State
}

\begin{abstract}
This chapter looks into the development of the Indonesian military after independence and the doctrinal development of the army that would provide the ideological and strategic foundation of the army's role in Indonesia's postcolonial state and society. It looks specifically into the army's territorial and rapid strike doctrines and its relationship to the rise of education for army officers. The influence of American doctrines of Civic Action and strike doctrines like the Pentomic Doctrine was channeled through the copying of American army officer curriculum in Indonesia's main army officer school, the Seskoad. American ideas of population capture through rural control and development was mirrored by the Indonesian army's development of counter-insurgency strategies. This strategy envisioned greater cooperation between the military and social scientists in developing strategies of control and development. It also envisioned the army as community leader and social engineers. Indonesia's developmental state can only function if the state can capture the population. Indonesia's counterinsurgency state is thus a central component for the New Order's developmental state and its roots can be found during the shift in army elite production in the 195 os.
\end{abstract}

\section{Keywords}

Indonesian military doctrine - counter-insurgency state - civic action - army dual function - army elite education

The formation of the dual function (dwifungsi) of the military was one of the cornerstones of both the Guided Democracy and the New Order. This chapter looks into the structural transformation that gave the military legitimacy within the 'developmentalist' project of the Guided Democracy state. I will first look at the gradual centralization of the army command around General Abdul Haris Nasution and the simultaneous creation of the military elites. Following the work of both Rudolf Mrazek ${ }^{1}$ and Ernst

1 Rudolf Mrazek, The United States and the Indonesian Military, 1945-1965: A Study of an Intervention (Prague: Oriental Institutet, 1978). 
Utrecht, ${ }^{2}$ I will look at the development of two different army doctrines: the territorial doctrine and the Tri Ubaya Cakti (Three Sacred Pledges). These doctrines represented ideological responses to two army factions: the territorial elite, who saw territorial management as the answer to problems of coordination; and the para-military elites, who focused on forward capability.

The question of control is essential here. The territorial doctrine aimed to expand military control over other institutions within the central and regional governments. The Tri Ubaya Cakti wanted the military, as a forward force, to be under the command of Sukarno. In both cases, the formation of territorial and strike-command elites required education. The creation of both a military managerial elite and a para-command elite was often predicated on American help. This was especially true for the para-command elites of the Guided Democracy, who obtained educational grants from the Kennedy Administration to go to the United States for training in the latest counterinsurgency tactics.

During the war, the Japanese controlled Indonesia through three separate military administrations run by the army and the navy, respectively. ${ }^{3}$ Because the politicians working under the Japanese were not allowed to coordinate at these levels, the local state presence took on a military form. As Kilcullen phrased it, 'The system was a means of coercion, propaganda, information collection, aid distribution and control over the population.4 Indigenous military organizations were prevalent in Java. ${ }^{5}$ PETA was the first military organization during the Japanese occupation that was commanded and controlled by Indonesians. By December 1944, PETA had sixty-six battalions in Java, with a total estimated force of over thirty-seven thousand soldiers by 1945 . The number of Indonesians involved in the various military and para-military organizations was estimated to be in the order of 2 to 2.2 million people.

2 Ernst Utrecht, The Indonesian Army: A Socio-Political Study of an Armed, Privileged Group in the Developing Countries (Townsville: Southeast Asian Studies Committee, 1978).

3 The $25^{\text {th }}$ army division held sway in Sumatra and the 16th division in Java. East Indonesia was under administration of the navy.

4 David Kilcullen, 'The Political Consequences of Military Operations in Indonesia', PhD dissertation, University of New South Wales, Sydney, 200o, 33.

5 Paramilitary organizations and schools were effectively used to instil radical nationalism. M. A. Azis, Japan's Colonialism and Indonesia (The Hague: n.n., 1955), 178. 
Military control of the territories contributed to ideas surrounding Indonesia's state-society relations. Guerilla operations weakened central command, resulting in the regionalization of military power. ${ }^{6}$ Robert Cribb writes that Nasution's principal contribution to the study of guerrilla warfare was his ability to depoliticize it, which contrasted with the politicization of people regarding social change that was espoused by generals such as Vo Nguyen Giap. ${ }^{7}$ The depoliticized nature of Indonesia's guerrillas stemmed from both Nasution's modernist aspiration to create a professional army and what can only be regarded as the Indonesian elite's distrust of the masses. ${ }^{8}$

Nasution's idea of guerrilla warfare was conceived while he was commander of the Java army in 1948, in which capacity he was the executive leader of both the military and the civilian authority. ${ }^{9}$ With the formation of a military government, the heads of the divisions automatically became military governors in their respective provinces. At the highest level (the district level, or tingkat keresidenan) was the Sub-Regional Military Command. Beneath this was the District Military Command, ${ }^{10}$ paralleling the district (kabupaten) level. Lastly, at the sub-district level (kecamatan) was the Sub-District Military Command..$^{11}$ Only at the village level was there a non-militarized executive. Yet, the lurah were now to report, not to their civilian line of command, but to the корм. ${ }^{12}$ The Wehrkreise, or independent units, formed the main substance of the mobile units. Most STM commanders were also Wehrkreise commanders. Indonesian political parties were never able to form a comparable administrative or organizational presence at the local or village level during this period.

This system predated the 1948 reorganization of a parallel military government and was created in October 1947 after the First Dutch Military

$6 \quad$ Kilcullen, 'Military Operations in Indonesia', vii.

7 Robert Cribb, 'Military Strategy in the Indonesian Revolution. Nasution's Total People's War in Theory and Practice', War and Society, 19/2 (2001), 150.

8 The masses were seen as a destabilizing and destructive force that required a vigilant redirection to productive purposes, in an image that equates it with river torrents and the government with the engineer's ability to redirect flows toward irrigation purposes. This is something that came up during the seminars held by the military and economists during the transition period of the Guided Democracy and New Order periods.

Salim Said, The Genesis of Power: Civil and Military Relations in Indonesia during the Revolution for Independence, 1945-1949 (Singapore: Institute of Southeast Asian Studies, 1981), 195-6.

10 The Komando Distrik Militer was later known for its abbreviation Kodam.

11 Said, The Genesis of Power, 195-6.

12 Salim Said, 'The Political Role of Indonesian Military: Past, Present and Future', Southeast Asian Journal of Social Sciences, 15/1 (1987), 17. 
Aggression. The aim was to create the illusion of the Siliwangi Division being under one command, even though many of its troops had spread out after the attack and partial occupation of West Java by Dutch forces in July and August 1947. The paralleling and subordination of the civilian administration to the military was followed by the decentralization of the local territories by the local military administration. ${ }^{13}$ The 'guerilla-ization' of the civilian administration was not limited to the executive administration but included many of the public services, including the police, judicial courts, taxation, information services, public health, education, manufacturing, and so forth. ${ }^{14}$

What happened during the revolutionary war was thus the development of a segmented army, whereby guerrilla warfare led to the creation of military fiefdoms at various local levels. The result was a territorial army, in which army divisions were manned and officered by people of the same locality. ${ }^{15}$ The failure of the political elites to extend their administrative authority outside the capital was compounded by the failure to effectively integrate the segmented military under civilian supremacy. The government had a modern vision of the army and backed ex-KNIL officers to lead the military. In 1945, when the army voted for Sudirman (1916-1950), an exPETA officer, to lead the military, the government had no choice other than to accept. ${ }^{16}$

Yet, as Ruth McVey has shown, the segmentation of the military was more than made up for by the fact that the army came out of the revolution without a significant divergence in ideological background. The left-leaning part of the army was destroyed during the Madiun rebellion. The conservative-colonial part of the army, the KNIL, achieved such notoriety that its participation after the transfer of sovereignty was made impossible, although some of those occupying positions at the chief-of-staff level were of KNIL extraction. Lastly, Islamic influence had been reduced by the end of the revolution, at which point the Muslims embarked on a protracted guerrilla war for the establishment of an Indonesian Islamic State. ${ }^{17}$

\footnotetext{
13 Said, The Genesis of Power, 199-200.

14 Nasution, Fundamentals of Guerrilla Warfare, 26.

15 Daniel Lev, The Transition to Guided Democracy: Indonesian Politics, 1957-1959 (Ithaca: Cornell Modern Indonesia Project, 1966), 12.

16 Said, The Genesis of Power, 98-103.

17 Ruth McVey, 'The Post-Revolutionary Transformation of the Indonesian Army', Indonesia, 11 (April 1971), 131-76.
} 
Benedict Anderson and Ruth McVey highlighted the division of the Indonesian army between the Dutch-educated KNIL officers and the Japanese-educated PETA, Laskar (paramilitary), and Youth (Pemuda) officers. The latter was the group that coalesced around the venerable war hero General Sudirman. Sudirman acquired mythical status for his role as the military, but also spiritual, leader of the wider army. The Sudirman group was based in the Diponegoro Division of Central Java and was highly motivated by the notion of the spirit of 1945 (semangat 45), an almost spiritual concept that attributed a positive value to the feelings of revolutionary fervour. ${ }^{18}$ This group was highly homogenous, with the majority of its officers being local Javanese.

The former group coalesced around the figure of former KNIL officer General Urip Sumohardjo. The group was based in the former colonial-army headquarters in Bandung and in the Siliwangi Division of West Java, and was composed of Dutch-trained, Westernized individuals, including Nasution and Tahi Bonar Simatupang. In 1945, Sumohardjo convened with thirteen former KNIL officers to pledge allegiance to Indonesia and to create a modern military. Thus, the divide in the military was between a Javanese-speaking, priyayicentred, PETA-trained group and a Dutch-speaking, cosmopolitan-intellectual, KNIL-trained group that contained a large proportion of Outer Islanders. ${ }^{19}$ The latter group's 'ability to deal with administrative problems, Republic-level politics and Dutch counterparts brought them into top positions in the course of the war for Independence. ${ }^{20}$

Although lacking some of the wider support that Sudirman enjoyed, the Sjahrir, and later Hatta, cabinets were supportive of the Bandung group and proceeded to elect people from the group to head the failed army modernization programme, the 'reconstruction and rationalization' (rekonstruksi dan rasionalisasi, re dan $r a),{ }^{21}$ coined by Nasution in 1948 . Nasution was appointed to the position of army chief of staff following the death of General Sumohardjo

18 Benedict Anderson and Ruth T. McVey, A Preliminary Analysis of the October 1, 1965 Coup in Indonesia (Ithaca: Cornell Modern Indonesia Project, 1971), 4. 'For soldiers of this kind, revolution is more drama than reconstruction, violent action rather than transformation of institutions. Soldiering itself is less a matter of techniques and skills, than the development of moral and spiritual faculties through a kind of modernized asceticism. A good soldier is identified by the kind of man he is rather than by his effectiveness on military exercises.'

19 Anderson and McVey, A Preliminary Analysis, 1-6.

$20 \quad$ Ruth McVey, 'The Post-Revolutionary Transformation', 134.

21 Utrecht, The Indonesian Army: A Socio-Political Study, 14. 
in 1948. Taking up the reins during the second military clash with the Dutch, Nasution would start to shape his ideas of the role of the military in society. ${ }^{22}$

With the end of the revolutionary war and the formation of the cabinet of the United States of the Republic of Indonesia, Prime Minister Hatta's policy to reduce the number of civil servants was followed by a focus on the military, which aimed to reduce the number of fighters through a series of rehabilitation programmes that would enable the transition of soldiers to civilian life. Unfortunately, the project was a failure. Transmigration and community development schemes would have helped thousands of former fighters to start new lives, ${ }^{23}$ but the implementation was less than satisfactory. ${ }^{24}$ In the new and democratic society of the 1950s, many of these former fighters became gangsters and henchmen, or took up roles in party and mass-membership organizations. At any rate, there was resentment of the civilian leadership's lack of concern for the well-being of the veterans of the revolutionary war. ${ }^{25}$

As chief of staff, Nasution would initiate the re dan ra again in 1950, with the consent of Prime Minister Hatta, in the hope of creating a small but modern army. This modernization was backed by many of the former KNIL officers, Minister of Defence Sultan Hamengkubuwono IX, and Secretary General of Defence Ali Budiardjo, a PSI sympathizer. Half of the partisan membership left the army, including officers. Consequently, there was a shift in the social background of the military officers. ${ }^{26}$

Members of Parliament voiced their support for the partisan grievances, attacking Nasution's efforts to modernize the army and his willingness to work with the Netherlands Military Mission (Nederlandse Militaire Missie, NMM) ${ }^{27}$ The parliamentary attack on the military leadership of Nasution and Simatupang led to the 17 October $195^{2}$ affair, in which Nasution's military faction tried to force President Sukarno to dissolve Parliament to allow Nasution to

22 Nasution, Fundamentals of Guerrilla Warfare, 25.

23 Report of the Social Ministry to the Prime Minister on the National Planning Board, Jakarta, 15 June 1951, Arsip Nasional Republik Indonesia, Jakarta (hereafter ANRI), Kabinet Presiden Republik Indonesia, 1950-1959. inv. no. 1277.

24 Abdul Haris Nasution, Tjatatan Sekitar Politik Militer Indonesia (Jakarta: Pembimbing, 1955), 349-50.

25 Nasution, Tjatatan Sekitar Politik Militer, 204.

26 Ernst Utrecht, 'The Indonesian Army as an Instrument of Repression', Journal of Contemporary Asia, 2/1 (1972), 58; Utrecht, The Indonesian Army: A Socio-Political Study, 7; R. E. Elson, Suharto, a Political Biography (Cambridge: Cambridge University Press, 2001), 61 .

27 The Dutch military mission was created in accordance to the Round Table Agreement to train the Indonesian armed forces in modern warfare for a period of five years. It ended in 1963 and was not renewed. 
take over as a dictator. Sukarno managed to defuse the situation and prevented the death of parliamentary democracy until later in the 195os. This action disgraced Nasution, who had his position as chief of staff annulled. Parliament voted in a new and more neutral army chief of staff: Major-General Bambang Sugeng. ${ }^{28}$

The shift of power towards the PETA faction in the military might have signalled a weakening of the modernizer faction that had supported reconstruction and modernization. Yet, chief of staff Sugeng made an honest effort to bridge the gap, culminating in the Yogyakarta Charter of February 1955 (Piagam Jogja 1955). With the support of the PETA faction, Nasution was able to swiftly move to dominate the army leadership. With the Indonesian Communist Party (Partai Komunis Indonesia, PKI) emerging as the fourth-largest party in Parliament after the 1955 election, Nasution increasingly called for the dissolution of the parties. In 1956, Nasution announced plans to rotate territorial commanders, which would weaken the hold of these military men and their fiefdoms, in order to slowly bring the fragmented and decentralized military under the leadership of Jakarta. Regionalist displeasure with Jakarta resulted in the PRRI ${ }^{29}$ rebellion. Some of the PSI and Masyumi leadership were involved in the rebellion. ${ }^{30}$ From 1955 , a relatively solid army was being created, supporting the position of Nasution..$^{31}$ Units and commanders reluctant to support Jakarta rebelled and eventually merged into the PRRI/Permesta ${ }^{32}$ movement, whose core consisted of Masyumi and PSI members.

\section{Anti-corruption and the Road to Power}

During Nasution's civilian stint (1952-1955), he published his ideas concerning the role of the military in modern Indonesian society. ${ }^{33}$ The hope that the 1955

28 Ulf Sundhaussen, The Road to Power. Indonesian Military Politics, 1945-1967 (Kuala Lumpur: Oxford University Press, 1982), 74-5.

29 PRRI stands for Pemerintah Revolusioner Republik Indonesia (Revolutionary Government of the Republic of Indonesia). It was a rebel movement led by regional army officers who were dissatisfied with Jakarta's policies and conduct.

30 Herbert Feith and Daniel Lev, 'The End of the Indonesian Rebellion', Pacific Affairs, 36/1 (Spring 1963), 32-46.

31 Sundhaussen, The Road to Power, 79-88; Crouch, The Army and Politics, 32.

32 Permesta was a rebellion based in Eastern Indonesia that centred on the city of Manado and was led by two TNI officers, Alexander Evert Kawilarang and Ventje Sumual.

33 Including the publication of his most important work on guerilla warfare. This was later translated into English and was particularly appreciated as a non-leftist approach toward guerilla warfare. 
election would create a non-corrupt and stable government was dashed when the elected cabinet proved to be as corrupt and incapable as previous ones. ${ }^{34}$ The period 1955-1957 thus represented a litmus test of the ability of the civilian leadership to stave off the increasingly hostile camp of anti-liberals. ${ }^{35}$ In 1955, at the Technical Faculty of the University of Indonesia, Sukarno reiterated his feelings for the democratic system by saying that 'parties can disappear but the universities must not.' ${ }^{36}$

On 14 September 1956, Nasution held a meeting with the National Security Board (Dewan Keamanan Nasional) specifically to design the course to be taken by the military to regulate the press and eradicate corruption. ${ }^{37}$ This was the public rationale for greater military involvement in civilian affairs, an effort justified by the failure of Parliament to enact an anti-corruption bill. ${ }^{38}$

The end of the Second Ali Sastroamidjojo Cabinet paved the way for aggressive military participation in executive affairs. When Sastroamidjojo handed over his mandate to the president at 10 am on 14 March 1957, it took Sukarno just thirty minutes to declare martial law. ${ }^{39}$ On 9 April, chief of staff and military ruler Nasution issued a Regulation on the Eradication of Corruption (Peraturan Pemberantasan Korupsi), whose broad definition of corruption included activities by persons or bodies which would, directly or indirectly, result in financial or economic loss to the state and persons holding a position and receiving a salary from the state, who, through the authority, power, or opportunity provided by their position, had, directly or indirectly, received a financial or material benefit as a result. ${ }^{40}$ On the same day, Nasution set up a system of military observers within the civilian bureaucracy to keep an eye on the government departments. ${ }^{41}$

On 28 March 1957, one day after Nasution's announcement that there would be an investigation of allegedly corrupt government officials, twelve civil servants were called in by the commander of the Military Police Corps (Corps

\footnotetext{
34 Feith, The Decline of Constitutional Democracy, $462-73$.

35 In particular, the Murba party, which came out as a supporter of Sukarno's Konsepsi later on.

36 Tangkas, 10 February 1955.

37 Duta Masyarakat, 17 September 1956.

38 Duta Masyarakat, 11 April 1957 and ANRI, Kabinet Presiden Republik Indonesia, 19501959, inv. no. 1939.

39 State of War and Siege (Staat van Oorlog en Beleg, мов).

40 Duta Masyarakat, 11 April 1957.

41 Army intervention on civilian affairs, National Archives of Australia, Canberra (hereafter NAA), A1838.
} 
Polisi Militer, CPM). ${ }^{42}$ In total, thirty-seven people were investigated, with eleven officially held by the CPM. Among these, several very important names stood out: Iskaq Tjokroadisurjo, former minister of the first Ali Cabinet; Ong Eng Die, former finance minister of the first Ali Cabinet; and Jusuf Wibisono, the Masjumi finance minister in the second Ali Cabinet. Sumitro Djojohadikusumo avoided incarceration as he was in Tokyo at a finance conference. ${ }^{43} \mathrm{He}$ went to West Sumatra to join the PRRI rebellion. ${ }^{44}$

The 9 April Regulation on the Eradication of Corruption was a milestone for Indonesia as it represented the first legal move to eradicate corruption; yet it was part of broader changes enacted by the military. ${ }^{45} \mathrm{~A}$ series of increasingly stringent regulations were created. ${ }^{46}$ In June $195^{8}$, a team was formed for the investigation of personal wealth and was ordered by the Justice Ministry (Kementerian Kehakiman) to carry out their work in all provinces other than those actively rebelling or under Dutch occupation. ${ }^{47}$ On the instructions of the executive, in 1958 the Anti-Corruption Commission (Komisi Anti-Korupsi), headed by Prime Minister Djuanda, completed a draft plan concerning the composition, tasks, and working methods of the Coordination Body for the Investigation of Personal Wealth and Property (Badan

42 Keng Po, 28 March 1957. These included Dr A. K. Gani, Mr Iskaq Tjokroadisurjo, Dr Ong Eng Die, Mr Kasman Singodimedjo, Mr Tan Po Goan, Dr Sumitro Djojohadikusumo, Mr Sjafruddin Prawiranegara, Mr Jusuf Wibisono, Dr Lie Kiat Teng, Dr Saroso, Arudji Kartanegara, Djamaluddin Malik, and others.

43 Duta Masyarakat, 9 May 1957; Bevelschrift voor aanhouding Prof. Soemitro, Nationaal Archief, The Hague (hereafter NA), inv. no. 382.

44 Duta Masyarakat, 3 o May 1957.

45 'Lampiran Perundang-undangan Peraturan Penguasa Militer', Hukum, 7-8 (1957), 16-166.

46 Panitya Anti Korupsi. Pemberantasan Korupsi, Kabinet Perdana Menteri Republik Indonesia, Jakarta, 20 May 196o, ANRI, Perdana Menteri Republik Indonesia, inv. no. 518; Nasional, 19 November 1958. On 27 May 1957, Nasution enacted a regulation to supervise property, followed by a 21 June 1957 regulation on the confiscation of materials gained through unlawful acts. A series of regulations was enacted throughout the period: on 16 October 1957, a regulation on the supervision of property owned by the military rulers and other state officials; on 28 October 1957, on the formation of a supervision team and its work programme and the guidelines for supervisors of property; on 16 December 1957, on the selling and limitation of use of confiscated materials; on 18 March 1958, on the supervision of the circulation of essential items; on 16 April 1958, on the investigation and prosecution of corruption and supervision of materials; on 14 May 1958, on the formation of a Coordination Body on Property Investigation; and on 9 August 1958, on the supervision, limitation of use, and sale of confiscated property. The Committee on Corruption Eradication finally created the Property Investigation Unit on 12 June 1959 .

With the exception of Central and South Sumatra, Sulawesi, the Moluccas, and West Irian. 
Koordinasi untuk Penjelidikan Kekayaan dan Harta Pribadi, BкPкнP) Because of the novelty of the entire approach, there were major difficulties to be overcome. ${ }^{48}$

The ВКРКHP created an inventory of the property of civil servants and state organizations. The law forced people to disclose land, houses and other property purchases, and wealth. ${ }^{49}$ Dozens of corruption cases had been brought to the courts by the end of 1959. Yet, it was also quite clear that the effects were rather disappointing. ${ }^{50}$ The military ruler had decreed the need to create a list of trustworthy companies that should be screened regularly and controlled by the Ministry of Finance and Trade (Kementerian Keuangan dan Perdagangan). The military ruler also saw the need to create financial supervision posts in each department and at the provincial and lower levels of government. The final regulation stipulated the formation of a Committee on Government Employee Rules (Panitya Negara Perantjang Undang-undang Kepegawaian) in an effort to stop civil servants from taking part in business and party politics. These anti-corruption efforts paved the way for the formation of the National State Apparatus Retooling Committee (Panitia Retooling Aparatur Negara, Paran). ${ }^{51}$

Despite this flurry of institution-building, army corruption expanded, linked to its takeover of the economy and the administration. A notable case included Suharto's demotion from his position as head of the Diponegoro Division on charges of corruption. Yet, for the most part, Nasution's institutional campaign failed. ${ }^{52}$ Nasution did not have the fortitude to push through his anti-corruption campaigns against army colleagues. He was also under attack from the communists, especially in the early 196os, who accused these institutions of building a power base for him for an eventual takeover. In any case, his efforts to assert his presence within the Guided Democracy state in institutions that he had built up were thwarted by President Sukarno, who replaced

$48 \quad$ NAA, Indonesian Corruption (1956-1970), A1838.

49 Pemberantasan Korupsi, Kabinet Perdana Menteri Republik Indonesia, Jakarta, 2o May 1960, ANRI, Perdana Menteri Republik Indonesia, inv. no. 518.

50 Pemberantasan Korupsi, Kabinet Perdana Menteri Republik Indonesia, Jakarta, 20 May 1960, ANRI, Perdana Menteri Republik Indonesia, inv. no. 518. The results for 1959 were: forty-eight cases in West Java, ten cases in Central Java, twenty cases in East Java, 292 persons required to give property details in Jakarta, nine cases in West Kalimantan, four cases in Aceh, and nine cases in North Sumatra. The Regional Military Government (Komando Distrik Militer or Territorium) handled these corruption cases.

$5^{1} \quad$ Laporan Panitia Retooling Aparatur Negara, ANRI, Bapekan, inv. no. 345.

$5^{2}$ He did take action against Colonel Ibnu Sutowo for smuggling in Tanjong Priok; see Harian Rakjat, 7 January 1959. 
Nasution's institutions with ones controlled by himself and appointed Ahmad Yani in 1962 to replace Nasution as head of the army. ${ }^{53}$

\section{$4 \quad$ Officer Education}

Army training had been conducted since the early years of independence. The National Military Academy (Akademi Militer Nasional, AMN) opened on 28 October 1945 in Yogyakarta and was the first of its kind. Its curriculum was modelled on the basic training of shoodan-tyoo, or platoon training, during the Japanese occupation. ${ }^{54}$ Complementing the colonial state's military academy in Bandung, the Royal Military Academy (KMA) was founded in 1940. On the Republican side, a school for officers opened in Malang, although it closed in 1948 after the Second Dutch Military Aggression. In 1953, a committee was established to design a complete military academy. This finally opened on 1 September 1957 as the AMN in Magelang, Central Java. ${ }^{55}$

In terms of staff and command schools there were two other academies, and these were more important to elite creation. The first was the Tjandradimuka School, which focused more on the ideological education of army officers; the second was the Staff and Command School (Sekolah Staf dan Komando Angkatan Darat, SSKAD). Both were located in Bandung. President Sukarno was a frequent lecturer at Tjandradimuka, a school that aimed to foster the spirit of the 1945 revolution. The school was built in 1951 under the directorship of Colonel Bambang Supeno, an ex-PETA officer. Tjandradimuka's nationalist and Javanese-oriented stance contrasted with SSKAD's social-democratic and PSI-dominated orientation. The school was considered by Nasution and Simatupang to be the centre of agitation against military modernization and they succeeded in closing it down in $1952 .{ }^{56}$

The SSKAD was founded on 17 October $195^{1}$ and aimed to equip future army officers with modern skills, including scientific administration, military analysis, and organizational know-how. Hatta made the needs of the

53 Abdul Harris Nasution, Memenuhi Panggilan Tugas, Jilid v: Kenangan Masa Orde Lama (Jakarta: Gunung Agung, 1985), 214. 'Yani gradually ended the autonomous position of the army and brought the head of the army directly under the authority of Sukarno and, later, as pioneered by the police, ensured that the army was obedient to the whims of Sukarno "without reserve".'

5420 Tahun Indonesia Merdeka, Vol. III (Jakarta: Departemen Penerangan, 1965), 217.

55 National Military Academy (Jakarta: Kementerian Penerangan, n.y.), 5.

56 Utrecht, The Indonesian Army: A Socio-Political Study, 41-6. 
post-revolutionary army clear: "The revolutionary period needs officers with flaming passion, burned by the dream of fighting and independence. In this period, bravery is rewarded more than capability [...] Often, assertiveness in action is more precious than the ability to estimate strategies and tactics in a thorough manner. ${ }^{57}$ After the revolution, 'aside from passion and assertiveness, the capability to weigh and decide, based on military knowledge, strategy, tactics, and knowledge of society is needed, ${ }^{58}$

By 1953, around 129 officers were being educated in the Netherlands. ${ }^{59}$ Others went to Fort Leavenworth, Kansas and Fort Benning, Georgia, in the United States. After 1954, the Netherlands wound down Indonesian attendance at its military academies, with the last Indonesian cadet leaving in $1957 .{ }^{60}$ In the same year, plans were laid for a command and staff college along the lines of Fort Leavenworth. SSKAD instructors went to the United States, Great Britain, Yugoslavia, and the Middle East to study the command and staff colleges there. In 1959, the SSKAD was renamed Seskoad. ${ }^{61}$ By the early 196os, people were also being sent to study in the USSR, Yugoslavia, Pakistan, and China.

In the initial years, the army relied heavily on the NMM as the main source of technical and tactical training. This included many of the teachers at the SSKAD. The nationalists and ex-PETA members were suspicious of the fact that the roles of instructors and teachers were being taken by former Dutch and KNIL enemies. ${ }^{62}$ Early in 1951, Simatupang reiterated why the NMM might not

57 BukuPeringatan Lustrum KeISSKAD, 17 Nopember1951-17 Nopember1956 (Bandung: SSKAD, 1956), 6. 'Masa revolusi menghendaki perwira yang semangatnja berapi-api, dibakar oleh tjita-tjita perdjuangan dan kemerdekaan. Dalam masa revolusi seringkali keberanian didahulukan dari ketjakapan, jang dianggap akan diperoleh berangsur-angsur didalam perdjuangan dan pertempuran. Seringkali ketegasan bertindak lebih berharga dari perhitungan strategi dan taktik jang dipikirkan dengan teliti.'

$5^{8}$ Of those 129 officers, twenty-nine went to the Royal Military Academy (Koninklijk Militaire Academie), sixty to the Royal Navy Institute (Koninklijk Instituut der Marine), and twenty-one to the Officer Reserve School (School Reserve Officieren); the rest went to a variety of schools and courses. Nota Menteri Pertahanan A. L. tanggal 26 Djanuari 1953, ANRI, Kabinet Presiden Republik Indonesia, inv. no. 1855.

59 Since 1951, a stream of Indonesian officers went to the United States and Western Europe, including the Netherlands, to finish their studies. In September 1951, twentyseven Indonesian cadets went to the KMA in Breda. See Wim Cappers, 'Nasi goreng en negerzaad. De opleiding van de Indonesische cadetten aan de Koninklijke Militaire Academie'. Armamentaria, vol. 38. 2003-2004. 258-283.

6o The ending of the Dutch-Indonesian Union in 1956 was important in the ending of IndoDutch military cooperation. Cappers, 'Nasi goreng en negerzaad'.

61 Gregory, 'Recruitment and Factional Patterns', 301.

62 Part of Nasution's Five-Year Plan for the army was to end the military mission. He thought the NMM was an imperialist ploy to weaken the army. A. H. Nasution, TNI (Jakarta: Jajasan Pustaka Militer, 1956), 18-39. As far as the KL/KNIL side was concerned, the 
be the most appropriate source of know-how: first, the Dutch did not have a deep knowledge and experience of military matters; second, there were psychological problems plaguing Indonesian-Dutch relations; and lastly, Indonesia's focus on defence was not in line with the more conventional warfare doctrine of the Netherlands. ${ }^{63}$

The NMM's role was to help Indonesia build up its army and it was paid to do so by the Indonesian government. ${ }^{64}$ Before 1953 , the NMM supplied the largest number of teachers for the college. Of the twenty-four teachers in total, six Dutchmen were permanent employees and twelve were temporary employees of the NMM. There were only three teachers from the Indonesian army and three civilian lecturers. By 1953, President Sukarno and the nationalists-leftwing coalition, alarmed by the 17 October 1952 affair, were pushing for the end of Dutch influence. In 1953, Indonesian teachers replaced all the NMM teachers.

The formal cessation of the NMM's involvement by March 1953 was followed immediately by overtures to Australia, Switzerland, West Germany, Sweden, and Norway to replace it. These proved unsuccessful and Indonesia then approached 'less neutral' countries such as the United Kingdom, the United States, and Canada but was equally frustrated. Attitudes in Indonesia had also become less positive towards foreign intervention in the military. By October 1953, however, the Australian embassy in Washington, DC had learned that the Americans had in principle agreed on the need for a Western military mission in Indonesia, although this had not resulted in a formal American military mission programme. ${ }^{65}$

By 1956, there were a total of fifty-six teachers at the SSKAD: five civilian lecturers, seventeen permanent lecturers, and thirty-four temporary lecturers. The permanent lecturers were either graduates of the SSKAD or from foreign

feeling was mutual. The paternalistic attitude of the Dutch instructors did not help either. Hans Meijer, Den Haag-Djakarta: De Nederlands-Indonesische betrekkingen, 1950-1962 (Utrecht: Het Spectrum, 1994), 391-3.

63 T. B. Simatupang, 'De Nederlandse Militaire Missie', translated from Indonesian, Perwira, 5 (1951), 182; NA, Ministerie van Buitenlandse Zaken, Hoge Commissariaat Bandung, 19501957 , inv. nos. $563-573$.

64 Nota omtrent de ontwikkeling van zaken in Indonesië in zoverre de verhoudingen binnen de Nederlands-Indonesische Unie en de belangen van Nederland daarbij betrokken zijn, Ministerie voor Uniezaken en Overzeesche Rijksdelen, Afd. Wetgeving en Juridische Zaken, no. 1, 's-Gravenhage, 23 Mei 1950. De Minister voor Uniezaken en Overzeesche Rijksdelen, J.H. van Maarseveen, NA, The Hague, Ministerie van Buitenlandse Zaken, Hoge Commissariaat Bandung, 1950-1957, inv. nos.: 556-566.

65 East Indies-Australian Educational and Cultural Interest in Indonesia, 1946-1951, Appendix B, Australian National Archives, Military Mission to Indonesia, A1838. 
institutions such as the Higher School for Warfare (Hogere Krijgsschool, HKs) in the Netherlands or Fort Benning and Fort Leavenworth in the USA. ${ }^{66}$ Much of the curriculum focused on military themes, including military law, military administration, tactical knowledge, use of artillery, military geography, military history, the maintenance of military technology, and so on. In 1956, out of a total of 2,210 classroom hours, 136 were dedicated to general knowledge, in particular political science, sociology, anthropology, and economics. Prior to 1956, only political science was taught. In the same year, military management was introduced. ${ }^{67}$ Between 1953 and 1958, six classes with curriculum B courses ran, with 357 officers attending. In March 1958, a new curriculum called the C-1 course was inaugurated, which had three classes and sixty-four attending officers. ${ }^{68}$ With the implementation of the C-1 course, socio-political themes expanded to fill 5 o per cent of the curriculum. ${ }^{69}$ This copied the curriculum of the American military staff and command school at Fort Leavenworth, ${ }^{70}$ with its eight teachers translating the field manuals, advanced sheets, and lesson plans for the SSKAD. ${ }^{71}$

In 1961, Seskoad opened up to non-military students from the Ministries of the Interior (Kementerian Dalam Negeri), Foreign Affairs (Kementerian Luar Negeri), Immigration (Dirjen Imigrasi), the Attorney General's Office (Kejaksaan Agung), the State Administrative Institute (Lembaga Administrasi Negara, LAN), and other institutions. ${ }^{72}$ There was greater inclusion of the social sciences and cooperation with other learning institutions, including the Higher Learning Institute for Police Science (Sekolah Tinggi Institut Ilmu Politik), and the political and social science faculties of Gadjah Mada University in Yogyakarta (since 1960), the Economics Faculty of the Universitas Indonesia (Fakultas Ekonomi Universitas Indonesia, FEUI) in Jakarta, and Padjadjaran University in Bandung (since 1962). A political science course on state defence

66 Wilujo Puspojudo, 'Perkembangan ssKAD', in Buku Peringatan Lustrum ke I sSKAD (n.p.: n.n, n.y.), 35 .

67 Puspojudo, 'Perkembangan SSKAD', $36-7$.

68 'Sedjarah Perkembangan Sekolah Staf dan Komando Angkatan Darat', Karja Wira Djati, 9 / 31 (July 1969), 9.

69 Gregory, 'Recruitment and Factional Patterns', 302.

70 Gregory, 'Recruitment and Factional Patterns', 302. Course C also expanded work of the Seskoad from purely educational to research and development.

71 'Perkembangan dan Kegiatan Seskoad sedjak Didirikan hingga Sekarang', Karja Wira Djati, 9/31 (July 1969), 40-1.

72 'Sedjarah Perkembangan Sekolah Staf dan Komando Angkatan Darat', 11. This was within the Defence Issue Orientation Course, which had four classes between the years 1961-1964. 
was taught at Padjadjaran University. ${ }^{73}$ From 1961, the experiences of the Mandala and Bhakti operations were used as case studies, ${ }^{74}$ as well as the antiguerrilla policies in Malaya and China and Yugoslavia's territorial warfare. ${ }^{75}$ The civic action part of the curriculum was strengthened. ${ }^{76}$ The Seskoad would play a central role in defining the civilian-military relationship and policy. ${ }^{77}$ The school thus had the important social functions of unifying the perspective of army leadership and creating an 'old boys' network. ${ }^{78}$

Nasution's second appointment as army chief of staff on 27 October 1955 gave the impetus for a stronger relationship between the SSKAD and other Staff and Command schools in many countries. Although the United States of America became one of the most important foreign centres for army training, with around one quarter of the army officers getting some education in American schools, Nasution was very eager to find places for SSKAD graduates at other army training schools. His trips abroad in the second half of the 195os brought possibilities for expanding the educational experience of the army, including to the UssR's Frunze Academy, the Fuhrungsakademie des Bunderswehr in West Germany, ${ }^{79}$ and the British Imperial Defence College. ${ }^{80}$

73 'Perkembangan dan Kegiatan Seskoad sedjak Didirikan hingga Sekarang', 53.

74 The Mandala operation was Indonesia's first forward intrusion into enemy territory as part of the military campaign against Dutch forces in West Papua inaugurated in 1961. The Bhakti operation was the locally based Civic Action programme conducted by the Siliwangi Division under General Ibrahim Adjie.

75 The territorial concept of Lieutenant General Dushan Kveder of Yugoslavia was published in Foreign Affairs magazine in October 1953 and Military Review magazine in July 1954. It was translated by the SSKAD at the end of the 1950s and was published in Indonesian in the army magazine Territorial in June 1961.

76 'Perkembangan dan Kegiatan Seskoad sedjak Didirikan hingga Sekarang', 46.

77 Between 1959 and 1966, Seskoad organized seven important seminars discussing Indonesia's military doctrine and its relation to the state and society. These included the First Seminar on Military Issues (1959-1960); the Second Seminar on Military Issues (January 1962); the First Army Seminar on the Tri Ubaya Cakti Doctrine (April 1965); and, lastly, the Revision Seminar on the Doctrine Tri Ubaya Cakti (August 1966). There was also a seminar on Civic Mission in July 1967, on Infantry doctrine in July 1968, and a preseminar on the Indonesian intelligence doctrine in February 1969.

78 Charles Donald McFetridge, 'Seskoad: Training the Elite', Indonesia, 36 (October 1978), 87-98.

79 This is where Sumitro, the important early New Order general, received his education. Saleh As'ad Jamhari, Sugiharta Sriwibara and Ramadhan K. H., Perjalanan Seorang Prajurit Pejuang dan Profesional: Memoir Jenderal TNI (Purn.) Soemitro (Jakarta: Sinar Cakra Sakti, 1999), 11.

8o Nasution, Memenuhi Panggilan Tugas, Jilid v, 59 and 147-6o. 
Aside from the Seskoad, there was another school that was highly important to the creation of the army elite. This was the Military Law Academy (Akademi Hukum Militer, AHM), which was initially founded to offer a legal course for military personnel between May $195^{1}$ and June 1952. Nasution issued the order to form a Military Law Academy and appointed the general secretary of the Ministry of Defence (Kementerian Pertahanan), Ali Budiardjo, to head its formation. ${ }^{81}$ In the whole of the 195os, only two generations graduated. The first group started their studies in September 1952, but due to the 17 September coup-like event and the havoc it wreaked throughout the military the cadets did not finish their two-year courses in less than four years. ${ }^{82}$

A second batch of students was enrolled in September 1954, but they did not finish their courses until 1960. This group had an even more interesting side job: helping to manage the nationalization of Dutch-owned companies. ${ }^{83}$ Many, like Major General Soekamto Sajidiman (who would play an important role in nationalizing the large trading firm Jacobson van den Berg into the state-owned company Juda Bhakti), ${ }^{84}$ Lieutenant Colonel Soedjiwo, and Lieutenant Colonel Sukotriwarno ${ }^{85}$ would continue their managerial roles after their military roles and ease themselves into longer careers in the business sector. ${ }^{86}$ The extent to which alumni of the Military Law Academy played a role in the nationalization is unclear. According to Sajidiman, he and his 'classmates from the Military Law Academy were instructed by the government to take over Dutch-owned corporations for the purpose of nationalization.' ${ }^{87}$ A commemoration booklet for the academy was sponsored by advertisements for various state-owned corporations, indicating the extensive spread of the cadets into state-owned businesses. ${ }^{88}$

81 D. Djiwapradja and E. Soewarna, Buku Peringatan Tudjuh Tahun Akademi Hukum Militer (Jakarta: Akademi Hukum Militer, 196o), 27.

$82 \quad$ Djiwapradja and Soewarna, Buku Peringatan Tudjuh Tahun, 35.

83 Djiwapradja and Soewarna, Buku Peringatan Tudjuh Tahun, 35.

84 Soekamto Sajidiman, The Tender Power. An Autobiography (Jakarta: Grafikaria Utama Sakti, 1978), 44.

85 O. G. Roeder, Who's Who in Indonesia (Jakarta: Gunung Agung, 1971), 388-9 and 404.

86 For more on military business, see Bambang Purwanto, 'Economic Decolonization and the Rise of the Indonesian Military Business', in J. Thomas Lindblad and Peter Post (eds), Indonesian Economic Decolonization in Regional and International Perspective (Leiden: KITLV Press, 2009), 39-58.

87 Sajidiman, The Tender Power, 44. 'Aku ditugaskan oleh Pemerintah untuk mengoper perusahaan Belanda bersama rekan-rekanku lainnya dari Akademi Hukum Militer dalam rangka nasionalisasi perusahaan2 Belanda.'

88 Djiwapradja and Soewarna, Buku Peringatan Tudjuh Tahun. Including Juda Bhakti (formerly Jacob van den Berg), Indevitra (formerly Borsumij), Ralin (formerly Philips), Satya Negara (formerly Internatio), and so forth. 
Like the Seskoad, the Military Law Academy was reliant on lecturers from Indonesia's major universities. Professor Djokosoetono, the University of Indonesia's legal specialist, was appointed as head of the teaching board. FEU I economists Tan Goan-Po and Widjojo Nitisastro taught economics, Soediman Kartohadiprodjo taught introductory law, Satochid Kartanegara taught criminal law, and Hazairin Adat, general law. Pieter Nicholaas Drost and Hendrik Jan Heerens were the only Dutch professors who taught at the academy, lecturing on international law and sociology, respectively. ${ }^{89}$ Many of the cadets at the academy and at the SSKAD/Seskoad not only had regular contact with professors and lecturers, especially from the UI, but also continued their educations, either at a university or through further courses (for instance, the management courses that were to become common in the latter part of the 195os). Thus, they would not only be destined to meet in the classrooms but also in boardrooms and on government committees.

\section{Guided Democracy and the Army}

The civilian political elite and the military elite translated the concept of Guided Democracy in very different ways. Although the ideas of efficiency, modernity, and the use of technical and managerial know-how were voiced by both these groups, the politicians never saw themselves as the primary executors of the technical details. If they did, this idea was immediately dashed by the failure of the Eight-Year Overall National Plan introduced in 196o and the deep economic malaise that set in in 1962. The military elite, meanwhile, because of their stronger corporate sense and more 'technocratic' education, expanded into civilian jobs without concerns about the primacy of technical know-how. General Suwarto, commander of the Seskoad, summed this up succinctly: 'De wereld van amateurisme is al voorbij.' 90

The army's crème de la crème had no qualms about experts and expertise. Unlike the politicians, many military officers were trained in technical fields and were open to educating themselves further, either at educational facilities in Indonesia or abroad. When the army expanded into the administration of government entities and companies, opportunities in civilian educational institutions opened up. Traditionally, military officers were trained in various

89 F. X. Sunatra, 'Beberapa Soal tentang Text-Book Thinking', in Djiwapradja and Soewarna, Buku Peringatan Tudjuh Tahun, 88.

90 Suwarto, Himpunan Karangan Djenderal Anumerta Suwarto (Bandung: Karya Wira Jati, 1967), 16. 'The world of amateurism is already over.' 
technical fields such as engineering, medicine, and administration, but by the early 196os, the employment of economists, sociologists, psychologists, and other social scientists was considered as standard in civilian engagement. This can be seen, for instance, in the use of sociologists and economists by the Army Rapid Strike Force (Resimen Pasukan Komando Angkatan Darat, RPKAD) during the West Irian infiltration campaign. ${ }^{91}$ Similarly, the Staff and Command School was opening the door to the social sciences. ${ }^{92}$

Rudolf Mrazek contends that there was a bifurcation of the Indonesian military elite that started in the late 1950s but had become especially pronounced by the 196os. This bifurcation was a result of the expansion of help with military training from various US military colleges, and the establishment of a new military doctrine and a new military elite with striking units that had a more outward, offensive spirit than Nasution's territorial ideas. The mid Guided Democracy period, the years 1962 and 1963 , were a watershed of major importance. As we will see, these were equally important years in the relationship between social science experts and the state, starting with the initially promising but latterly disappointing Economic Declaration (Deklarasi Ekonomi, Dekon). ${ }^{93}$ This period saw hope for greater expert participation in national policymaking and planning. The rise of General Yani to replace General Nasution as army chief of staff was one of the pivotal points in this change. As a member of one of the army's strike groups, Yani had no qualms with publicly opposing military involvement in the state and the economy.

In Chapter 1, elite divergence was explained as a generational difference between the old, colonially educated intellectuals of the 1928 generation and the newer, American-educated experts of the 1945 generation. If we follow Mrazek's line of reasoning, the divergence among the military elite was one of educational experience and generational difference:

Until the mid-sixties, the Indonesian army had been officered by the first generation of officers who had matured during the forties or before, and who were now reaching an age close to retirement. We know for sure that by the mid-sixties there served in the Army a great number of young officers trained either in the United States or elsewhere abroad, as well as several thousands of new Magelang Military Academy graduates. ${ }^{94}$

91 Kenneth Conboy, Kopassus. Inside Indonesia's Special Forces (Jakarta: Equinox, 2003), 71.

92 Pauker, The Indonesian Doctrine of Territorial Warfare, 28 and 37-41.

93 Simpson, Economist with Guns, 92; Eric J. Chetwynd, 'The Indonesian Stabilization Attempt of 1963: A Study in the Economics and Politics in Indonesia', Master's thesis, American University, Washington DC, 1965, 38-9. 
The territorial doctrine would become the basis for the civic action programme and other military activities in civilian areas. As we saw above, Nasution began to formulate the doctrine during the Indonesian revolution. In 1958, Nasution appointed Commodore Siswadi and Colonel Soewarto, the PSI-leaning deputy commandant of Seskoad, to head an ad hoc committee for the development of the armed forces, which included the implementation of this doctrine.

The idea of a territorial doctrine lay in the concept of total warfare, one that incorporated the entirety of the nation within a defence strategy. This strategy was assumed to be the only means by which Indonesia could effectively defend its national interests in time of war. Because of the weaknesses of the military, the only way in which Indonesia could offer any effective form of resistance was through a guerilla-based strategy that utilized Indonesian society as part of its heavy warfare. ${ }^{95}$ Many within the military elite assumed that there would be another catastrophic world war within their lifetime. Thus, war was to be waged as an economic, social, political, and even cultural offensive, instead of a merely military offensive. Mao Zedong's conception of the army as a fish and the people as water meant that it was important for the fish to have the support and control of the people. Kveder's idea of territorial warfare also leaned heavily on this assumption of mass control. ${ }^{96}$

It is not hard to see how total warfare would mean greater control of society by the military. An article in the magazine Territorial stated: 'We (the army) shall manage and we shall control so that they (the people) can be invited, moved, and deployed with their positive power in the general goal of state defence, security, and development. ${ }^{97}$ This was achieved through the expansion of military duties into civilian areas. Civic Action programmes were used by the military for rural population control and to limit the communist influence.

Civic Action was part of the army's idea of territorial management. The expansion of military leaders into nationalized businesses and the application of Civic Action happened before the formal announcement of the doctrine. Civic Action did legitimize, however, the position of army officers as the managers of companies, rural areas, and whole provinces. The army was transformed into a managerial elite and, in the process, its officers mingled with the nascent civilian managers. Because of the expansion of military jobs into the civilian field,

95 Pauker, The Indonesian Doctrine of Territorial Warfare, 11-17.

96 Pauker, The Indonesian Doctrine of Territorial Warfare, 34-7.

97 'Suatu Konsepsi Pembinaan Wilajah sehubungan dengan Perang Wilajah dalam rangka Pertahanan Nasional', Territorial, 1/2 (January 1962), 3. 
organizations such as Seskoad followed suit and expanded their educational offerings, as the shift towards the C-1 course has shown. Thus, there was an inclination to connect young army officers with young, American-trained social science experts in order for them to share ideas. This idea of military-cumcivilian managerial elite control runs counter to the Guided Democracy's focus on the societal incorporation of the intellectual politician within the leadership. Instead, education fostered the creation of a military-civilian expert, thus creating a leadership that saw control as more important than incorporation.

The idea of military men as managers was legitimized through publications. Magazines like Manager and Fortuna, both targeting an audience of nascent professional managers, were very accommodating to the voices of military managers. Nasution and Ibrahim Adjie, for instance, wrote various pieces for these magazines. ${ }^{98}$ The magazines themselves discussed Civic Action and other military managerial programmes without a hint of suspicion. Likewise, army-issued magazines, such as Karya Wira Djati and Territorial, offered space for expert civilian managers to discuss management issues, including military management ones.

Territorial control, like its civilian managerial counterpart, thus required mass control: '[W] e must control mass opinion in our effort to develop our national morals. ${ }^{99}$ Terms such as $p s y$-war were bandied about in military articles on Indonesia. Counter-insurgency tactics used methods to effectively counter or reduce the hostility of the population in enemy territory. The military managers needed to implement several basic elements within their territory: the management of the ideology and psychology of the community; the management of the social, economic, political, and logistical issues of the community; the management of the human mindset as the subject of people's resistance; the management of the government in times of war or danger; and the implementation of a special rural development programme..$^{100}$

Territorial management was an important subject for army leaders like Nasution, but this conflicted with Sukarno's efforts to use the military for his foreign policy. In this regard, it is important to understand the shift in power from Nasution to Yani and the shift in doctrine from territorial to Tri Ubaya Cakti. Under attack from both Sukarnoists and the communists, civilian

98 For instance, A. H. Nasution, 'Kata Sambutan', Manager, 4/36 (April 1963), 4-9; Ibrahim Adjie, 'TNI dan Civic Mission', Manager, 4/36 (April 1963), 10-15.

99 'Suatu Konsepsi Pembinaan Wilajah', 8. '[...] kita harus mengendalikan opini masa untuk ditudjukan ke arah pembentukan moril nasional jang tinggi dengan semangat melawan jang berkobar-kobar.'

100 'Suatu Konsepsi Pembinaan Wilajah', 4-27. 
experts and military managers alike sold the territorial doctrine as one that could support the Guided Democracy's development plans.

\section{$7 \quad$ American Influence and Its Counter-balance}

The new generation that had had a foreign military education understood the territorial doctrine and had the technical capabilities that would result in a further bifurcation of the military elites. Before 1958, some $25^{\circ}$ Indonesian officers had been trained in the United States. Another five hundred officers were trained between 1958 and 1962. The spike between the years 1962 and 1964 was significant, with more than three thousand military officers going to the United States for further training. The total number of officers with American exposure was thus around four thousand, a very significant proportion within the armed forces. ${ }^{101}$ Many officers had been educated at Fort Leavenworth, which supported a social scientific approach to counter-insurgency.

The military's strike groups - including the Army General Reserve (Tjadangan Umum AD, or Tjaduad, later Kostrad); the Army Special Command (RPKAD, later Kopassus); the Police Mobile Brigade (Brigade Mobil, Brimob); the Marines (кКо); the Flying Corps; and the Special Air Force Group Airborne (Linud) - had had a different educational experience. They had learned technical skills and the latest counter-insurgency methods applied in the Vietnam War. The Indonesian military elite aimed to make the country's strike units comparable to American ones, borrowing the American Pentomic doctrine. ${ }^{102}$ The United States Senate Committee responsible for aid to Indonesia heard the testimonies of experts who 'consider[ed] the Indonesian army as one of the most skilful in the world at small unit operations in swamps and jungles'. ${ }^{103}$ American assistance also came in the form of providing Indonesian strike units with some of the latest US military gadgets. This strike force elite grew to differentiate themselves from the territorial elite, because they considered the territorial elite to be slothful, corrupt, and wealthy because of their civilian assignments. At the same time, the territorial officers were jealous of the paracommand units and their better equipment and greater prestige. ${ }^{104}$

\footnotetext{
101 Peter Dale Scott, 'Exporting Military-Economic Development: America and the Overthrow of Sukarno, 1965-1967', in Malcolm Gladwell (ed.), Ten Years Military Terror in Indonesia (Nottingham: Spokesman Books, 1975), 236; Ruth McVey, 'The Post-Revolutionary Transformation of the Indonesian Army: Part II', Indonesia, 13 (April 1972), 169.

102 Kostrad by 1965 was headed by then Brigadier-General Soeharto.

103 Mrazek, The United States and the Indonesian Military, 83-4.

104 Mrazek, The United States and the Indonesian Military, 46.
} 
It would be too hasty to conclude that the difference between these elites was profound. Differences between the army, navy, air force, and police had bigger consequences in the later New Order period. Ernst Utrecht interprets the relationship differently. He divides the elites into 'Field Officers' and 'Managers' and, accordingly, defines their relationship as one of mutual symbolism rather than the antagonistic competition implied by Mrazek. The managers provided the para-commanders with the money to operate their units and also to indulge in the lifestyle of the elite. ${ }^{105}$ The expansion of the 'experts' developed along two general lines: a pinnacle level of professional scientists whose duty was to design national policies and plans, and a middle level of managers whose duty was to run the government offices and stateowned factories.

The relationship between the Indonesian army, American-educated intellectuals, and their American counterparts has been a leitmotif of leftist Cold War literature on the CIA. This was perhaps most succinctly expressed in David Ransom's paper, which coined the term the 'Berkeley Mafia', the name given to the economic technocracy that engineered much of the New Order's economic policies. ${ }^{106}$ Such an analysis tends to overlook the weaknesses of the proAmerican factions, especially the American-educated economists and social scientists and, by 1964, the despair of the US State Department's Indonesian planners, as Sukarno lurched towards intensifying the friendship with Maoist China.

One of the most important individuals in this relationship was Guy Pauker. He collaborated on a report funded by the Council on Foreign Relations, published in 1959, that saw the Indonesian army as 'among the most capable leaders of Indonesia.'107 Pauker had first visited Indonesia in 1954 as researcher with the Ford Foundation-MIT Modern Indonesia project. In 1958, he became a RAND consultant whose role was paid for by the CIA. In 1959, he took up residence as chairman of Berkeley's Department for South and Southeast Asian Studies. In his role at Berkeley, he formed good relationships with not only Sumitro Djojohadikusumo but also Widjojo Nitisastro and Mohammad Sadli. He also grew close to Nasution and the commander of Seskoad, Colonel Soewarto. ${ }^{108}$

\footnotetext{
105 Utrecht, 'The Indonesian Army as an Instrument of Repression', 61.

106 Ransom, 'The Berkeley Mafia'.

107 Scott, 'Exporting Military-Economic Development', 219.

108 Scott, 'The United States and the Overthrow of Sukarno, 1965-1967', Pacific Affairs, 58/2 (Summer 1985), 247-8.
} 
Peter Dale Scott reasons that Pauker was central to the introduction of the dual function of the military and that he persuaded Nasution to convince Sukarno to let the army participate in the government and the economy. There is no doubt that the ideas of military development were, in part, inspired by American thinking, yet thoughts about the dwifungsi had already clearly been part of Sukarno's corporatist idea and Nasution's revolutionary manual. On 30 August 1956, an ad hoc committee was created, headed by Colonel Azis Saleh, to study the ways in which the Indonesian National Armed Forces (Tentara Nasional Indonesia, TNI) could participate in the development of the state. ${ }^{109}$ In 1958, Nasution set up the Committee on Army Doctrine (Panitya Doktrin Angkatan Darat), headed by Lieutenant Colonel Suwarto and Colonel Mokoginta, which would result in the introduction of the army doctrine of Territorial Warfare (Perang Wilayah). ${ }^{110}$

The United States played a key role in the rise of Civic Action, especially in its 196os ' form. In 1962, Pauker invited Soewarto to the RAND Institute to show him how RAND organized the 'academic resources of the country as consultants'. At the same time, the Ford Foundation provided a \$2.5 million grant for training courses. David Ransom pointed out that the Ford Foundation used their contacts at the FEU I to influence officers within the Seskoad. By 1962, University of Indonesia economists were regularly visiting the Seskoad, where they taught the 'economic aspects of defence' and would discuss the national situation, sometimes late into the night. ${ }^{111}$ According to Pauker, after Suwarto's visit to the RAND Institute, he appointed four or five economists as the army's high-level civilian advisers. According to Robert Shaplen,

The task of Suwarto and his staff [...] was to convince as many as possible of the army's 150 general officers and 400 colonels that it was their responsibility to maintain the delicate balance between the representative democratic principle, which makes parties and policemen a 'necessary evil' in any polity, and the corporatist principle which gives the army the means to participate in the government without creating a military dictatorship. ${ }^{112}$

\footnotetext{
109 Duta Masyarakat, 30 August 1956.

110 Sundhaussen, The Road to Power, 138.

111 David Ransom, 'Ford Country: Building an Elite for Indonesia', in Steve Weissman (ed.), The Trojan Horse. A Radical Look at Foreign Aid (Palo Alto: Ramparts Press, 1975), 101-4.

112 Robert Shaplen, Time Out of Hand. Revolution and Reaction in Southeast Asia (New York: Harper \& Row, 1969), 146.
} 
There is no doubt that the army had a close affinity with the United States, but, as among the wider Indonesian elite, there was a degree of suspicion towards it. Nasution was always looking for potentially useful doctrines and curricula among those used by other nations. Chinese and Yugoslavian materials were translated and used. The territorial doctrine was also inspired by Mao Zedong's interview with Edgar Snow in Red Star Over China and the army's experiences in the revolutionary war. ${ }^{113}$ According to Suwarto, the article 'Territorial War: The New Concept of Resistance', written by the Yugoslavian general Dushan Kveder, was very influential, with an Indonesian translation available at the Seskoad from 1958; the officers were also required to read Vladimir Dedijer's 'Tito Speaks' and other translated Yugoslavian texts. ${ }^{114} \mathrm{It}$ was planned that by 1965 , the army would use Indonesian doctrines for 60 per cent of its curriculum; in 1964, it was stipulated that all departments that focused on doctrinal research and development would be assigned an officer who had graduated from the Soviet Frunze Academy as a counterbalance to the American influence. ${ }^{115}$

\section{The Military Strike Force and the Shift in Military Doctrine (1962-1965)}

During the revolutionary war, the TNI had used both guerrilla and counterinsurgency tactics. This two-method approach was rare amongst the experiences of twentieth-century independent revolutions. Guerrilla warfare, with its unique command-and-control structure, is inherently decentralized, lessening the control of the centre, while counter-insurgency tactics tend to increase the degree of control of local military leaders at the expense of both local political leaders and the centre. The tendency on both accounts is to weaken the central command structure of the army and enhance control by regional and local army commanders. ${ }^{116}$

David Kilcullen has argued that the expanding political influence of the TNI during the period $1945^{-1965}$ was the result of a continuous but uneven development and deployment of TNI's insurgency/counter-insurgency measures. ${ }^{117}$ However, the control of local territories had its roots as far back as the Japanese

\footnotetext{
113 Pauker, The Indonesian Doctrine of Territorial Warfare, 8-9.

114 Pauker, The Indonesian Doctrine of Territorial Warfare, 34-7.

115 'Perkembangan dan Kegiatan Seskoad sedjak Didirikan hingga Sekarang', 52-3.

116 Kilcullen, 'Military Operations in Indonesia', 6.

117 Kilcullen, 'Military Operations in Indonesia', 27.
} 
occupation. Although strike forces had existed much earlier, the early 196os were a watershed in the Guided Democracy. The development of a militarywide strike force, the Army General Reserve, in $1963,{ }^{118}$ which functioned as an umbrella force composed of selected battalions of various strike groups, was a culmination of the shift in military emphasis from territorial commands to strike groups.

Hidajat Moekmin, writing after the fall of the Guided Democracy, said:

Without declaring the reasons, the (active and free foreign) policy was silently left behind. It was then replaced with the politics of confrontation and political axes. Not satisfied, they wanted the defence policy to follow the confrontation policy. Without understanding the requirements, they forced a change to the defence policy so that it would be more 'offensiverevolutionary', a term that is often used more to refer to the fighting spirit (semangat) than the facts. These opportunists were everywhere, even within the armed forces. This group was always searching for personal aggrandizement by proclaiming themselves to be the most revolutionary, discrediting the Territorial Doctrine as a worn-out concept that was not revolutionary, and suggesting that it should be replaced with something new. ${ }^{119}$

The period after 196o also saw the development of a specific military doctrine within the Seskoad that would result in the creation of the Tri Ubaya Cakti doctrine expounded in $1965 .{ }^{120}$

118 This was the embryo for the Kostrad, an important, influential para-military unit during the New Order.

119 Hidajat Moekmin, 'PKI versus Perang Wilajah. Penilaian Kembali suatu Doktrin', Karya Wira Djati, 6/21 (1966), 13. ‘Tanpa menjebutkan setjara djelas sebab2nja maka politik ini kemudian ditingalkan. Itupun setjara diam2 sadja. Selandjutnja diganti dengan Politik Konfrontasi dan Politik Poros. Tidak terbatas hanja sampai sekian mereka menghendaki agar djuga Politik Hankam disesuaikan dengan Politik Konfrontasi itu. Tanpa melihat persjaratan jang ada mereka mengusahakan agar politik Hankam kita dibuat lebih "offensive-revolutioner", kata2 jang sudah terlalu sering hanja diisi dengan semangat daripada kenjataan. Golongan opportunis dengan "pamrihisme" memang ada dimana2, djuga dalam tubuh $\mathrm{AD}$ sendiri. Golongan inilah jang selalu berusaha mentjari "grandeur" pribadi dengan menepuk dada bahwa mereka jang paling revolusioner dan mentjap Konsep Perang Wilajah sebagai konsep jang using, jang tidak revolusioner dan harus diganti dengan Doktrin jang sama sekali baru.'

120 'Sedjarah Perkembangan Sekolah Staf dan Komando Angkatan Darat', 13. 
The most important strike force of the army was the Army Rapid Strike Force, which was created by the Siliwangi Division under Colonel Alex Kawilarang. On 16 April 1952, Kawilarang formally authorized the establishment of the Command Unit (Kesatuan Komando, Kesko). In early January, the Kesko unit was transferred by central command to be under the direct authority of the army chief of staff. On 18 March, it was rechristened the Army Command Corps (Korps Komando Angkatan Darat, KKAD). On 25 July 1955, the Army Command Corps was upgraded to the Army Commando Force Regiment (Resimen Pasukan Komando Angkatan Darat, RPKAD). After the success of ending the PRRI/Permesta rebellion in February 1958, educational assistance for the army was offered by both the US and England, in an effort to mend the relationship between Jakarta and the rebellions. ${ }^{121}$

The American Special Forces model was very different from what had existed in Indonesia. The Indonesian model was based on 'self-sustained units that performed unconventional tasks for long periods far behind enemy lines'. The units were intended to win the hearts and minds of the people and included an interpreter and a medic to help the villagers. Each unit included four combat engineers to assist in demolition duties, two doctors, two social scientists, and an economist, and was called a Special Forces Detachment (Detasemen Pasukan Chusus, DPC). ${ }^{122}$

The shift in assistance and funds towards training mobile forces represented a shift of attitude among the elites away from the concept of territorial forces. As Mrazek contends, '[T]hus the development after 1958 and during the early sixties left its deep imprints in the structure and ideology of the Indonesian armed forces. While before $195^{8}$ the mobile striking units represented only very small islands in the vast sea of the territorial army, during the early sixties they acquired in many aspects a decisive position in the Indonesian military establishment.'123 An important development that mirrored other areas of the military elite was the use of social scientists as a viable part of military missions. ${ }^{124}$

With the change from the pro-Territorial General Nasution to the proMobile Force General Yani as Sukarno's chief of staff, the ideological shift towards an offensive military policy became more pronounced. Yani had

\footnotetext{
121 Conboy, Inside Indonesia's special forces, 13-27.

122 Conboy, Inside Indonesia's Special Forces, 86-7.

123 Mrazek, The United States and the Indonesian Military, 45.

124 Conboy, Koppasus. Inside Indonesia's Special Forces, 86-7.
} 
received military training in Tokyo during the Japanese occupation. He was also among the first Indonesian officers to attend the Command and General Staff School at Fort Leavenworth in 1955. Before returning to Indonesia, he took a two-month course on special warfare in England. ${ }^{125}$ Nasution appointed him chief of operations and then deputy director of intelligence. Under him, American-trained officers were given the most influential positions within the staff and command. It was, of course, ironic that as Nasution was being removed from office, the Americans were fully backing his territorial doctrine because they believed that a military focus on population capture was much more in line with the idea of stamping out communist influence. ${ }^{126}$ The aggressive doctrine espoused by the mobile-force elite was a cause for concern, since it destabilized the domestic situation, something which the communists could take advantage of. ${ }^{127}$

The rise of Ahmad Yani and his outward-looking, aggressive stance was in line with Sukarno's views and his increasingly agitated policy towards the Dutch presence in West Papua. With massive Soviet help, the military, especially the navy and air force, was equipped with impressive hardware, the likes of which were non-existent in any other Southeast Asian country. By 1962, the Soviet Union had provided hundreds of tanks, armoured personnel carriers, artillery pieces and guided missiles, jets and fighter bombers, and ships. Indonesia felt far more prepared to make the move towards an offensive strategy against the Dutch, which was a noticeable difference to the guerrilla warfare that had been Indonesia's default strategy during the revolutionary war.

The declaration of the Tri Ubaya Cakti doctrine was made during a military seminar held at the president's request from 2 to 9 April 1965 at the Seskoad in Bandung. A total of fifty-one high-level officers, eighty-nine mid-level officers, and thirty-two civilian and military experts converged to discuss military doctrine. ${ }^{128}$ The seminar was to cover three doctrines/issues: the military Karya, the revolutionary war, and the development of the potential for an Indonesian revolution. These discussions envisaged a new government programme

\footnotetext{
125 Soehardiman, Kupersembahkan kepada Pengadilan Sejarah. Otobiografi Soehardiman (Jakarta: Yayasan Bina Produktivitas, 1993), 210.

126 Mrazek, The United States and the Indonesian Military, 54-9 and 75-81.

127 Mrazek, The United States and the Indonesian Military, 42.

128 Moekmin, 'PKI versus Perang Wilajah', 7.
} 
that would use the military in a creative-destructive (penjebolan-penciptaan) nation-building programme. The military was to harness total participation by the people within a specific offensive and defensive programme. Socially, culturally, and economically, the entire society was to participate in the protection of the nation-state.

This active call for the state to destroy elements within and without society was telling for subsequent state-society relations. Sukarno asked:

What is the goal of our revolution, and what is the work that we want the revolution to accomplish? To destroy. Our revolution is to destroy and to plant. Now, if we think deeply, what is it that we must destroy? What we have to destroy and destroy right now is imperialism, colonialism, neocolonialism, capitalism, all of which has been written in the preamble to our constitution. ${ }^{129}$

Such theoretical enemies were fleshed out as per the discussion at a previous Seskoad seminar. Discussions on territorial management as early as 1962 had highlighted the enemies of the state. ${ }^{130}$ Ideologically, these were individualism and liberalism, international communism, religious fanaticism, atheism, isolationism, autarchy, and chauvinism. Politically, they were imperialism and colonialism, federalism and separatism, dictators, tribalism, and regionalism. Socio-economically, they were capitalism, feudalism, cosmopolitanism, negative foreign culture, reformism, conservatism, cynicism, and apathy. ${ }^{131}$

The state, through military coercion, was to root out the infiltration of foreign ideas in the minds of its populace. In order to achieve this, indoctrination programmes were devised to reach various sectors of society. Thus, the 'educated sector' of the population was to be indoctrinated through rational persuasions. The general public was to be seduced by material incentives. The

129 In Doktrin Perdjuangan TNI 'Tri Ubaya Cakti'. Buku Induk (Malang: LP IKIP, 1965), 20. 'Apa tudjuan revolusi kita, dan jang kita kerdjakan dengan revolusi kita itu apa? Menggempur. Revolusi kita itu mendjebol kataku, dan menanam. Nah, kalo kita fikir benar2, revolusi adalah mendjebol; apa jang harus kita djebol, dan apa jang sedang kita djebol. Jang harus kita djebol dan jang sekarang kita djebol jaitu imperialisme dan kolonialisme, neokolonialisme dan kapitalisme, sebagaimana jang tertulis dalam kalimat jang pertama daripada preambul.'

130 The focus of these discussions was to debate and create regional operational, logistical, and management patterns, but eventually a much wider and intrusive population control at the individual level was discussed. The rise of the New Order Man must be attributed to the ideas discussed within these seminars.

131 'Seminar Seskoad Kedua, 3-8 Januari 1962', Karja Wira Djati, 2/8 (1962), 70-1. 
orthodox groups were to be given informative seminars that would broaden their horizons, and the separatists would be corrected through political incentives. The major enemies of the state were thus defined as its own population: the educated person and his 'liberal and capitalist' tendencies, the general public and its 'communistic ideas', the orthodox group and its Islamic fanaticism, and the separatists and their wayward ideas of nationhood. ${ }^{132}$

The idea of a Total People's Defence (Pertahanan Rakjat Semesta) had been discussed in earlier seminars at the Seskoad and this envisaged a threepronged approach towards defence: a conventional force consisting of the military, a non-conventional force consisting of a Civil Defence (Pertahanan Sipil or Hansip), and a People's Resistance Force (Perlawanan Rakjat). The Civil Defence would be organizationally under the head of state to ensure unity of command. ${ }^{133}$ The roots of this strategy were derived from the total-warfare doctrine that the Japanese had introduced to the Indonesian youth through the formation of military units (daidan) within community organizations (tonarigumi). ${ }^{134}$

Yet, the Revolusi component of the doctrine represented a change from earlier ideas, from a focus on internal enemies to external ones. This shift was possible on the condition that Sukarno's control of the army was total; this was only possible after Nasution had been neutralized and Ahmad Yani installed. Sukarno's speech during the seminar provided a glimpse into the difference. Sukarno said:

... our revolution has been side-tracked. Our army followed along with a side-tracked defence policy. This was a side-track from the revolution. Our defence policy has been force-fed by the neocolonialist powers. Several of our officers who have obtained foreign educations [...] were taught defence strategies, large and small tactics, all of which aimed to convince us that 'the possible enemy will come from the north'. We have been 'force-fed' those words. Thus, we were taught that if we want to defend the country, we have to face the north, not the south, west, or east. ${ }^{135}$

132 'Seminar Seskoad Kedua, 3-8 Januari 1962', Karja Wira Djati, 2/8 (1962), 70-1.

133 'Pertahanan Rakjat', Karja Wira Djati, 3/1 (July 1963).

13420 Tahun Indonesia Merdeka, Vol. III, 22.

135 In Doktrin Perdjuangan TNI 'Tri Ubaya Cakti', 21. '... revolusi kita menjeleweng, Angkatan Bersendjata kitapun ikut2 didalam ia punja defence policy menjeleweng, njeleweng daripada revolusi itu. Defence policynja pada waktu itu, kita "ditjekokkin", djustru oleh fihak Nekolim. Beberapa hal jang salah misalnja saja kenal beberapa Opsir, Perwira, dapat didikan dari Luar Negeri, eh, Parman djuga manggut2, didikan dari luar negeri, disitu 
Sukarno insisted that the enemy was the West, the neocolonialist powers headed by the United States of America.

This 'rediscovery of the revolution' was a realignment of Indonesian international interests, with Indonesia's confirmation of its position within the non-aligned Third Power Bloc, the Newly Emerging Forces. The military played an important part. Sukarno continued: 'So the military, that word is closely inherent, very much inherent to the idea of the enemy. What is the purpose of war? It isn't purely for self-defence. The purpose of war is to destroy the enemy; no one conducts war without having this purpose to destroy, to defeat the enemy.'136 This doctrine was in line with Sukarno's increasingly erratic view of the world (the Nefo and Oldefo classification) and Indonesia as a beacon of revolution.

This doctrine was significantly revamped after the fall of Sukarno in 1965 . By the Second Army Seminar, held from 25 to 31 August 1966, after the fall of the Guided Democracy, the belligerent tone had disappeared. Instead of a revolutionary army, the army was depicted as a modern one: an organization with experts and their expertise. Thus, the values of military leadership were still extolled, with leadership ideals based on almost feudal characteristics alongside modern, managerial leadership ideals. ${ }^{137}$ 'The New Order wants a more realistic and pragmatic order, although it does not leave behind the idealism of struggle.'138

diadjarkan, hal2 jang mengenai defence strategy, taktik besar, taktik ketjil, pada dasarnja jalah, diadjarkan kepada kita itu "the possible enemy will come from the North". Kita "ditjekokkin" begitu "the possible enemy will come from the North". Malahan segala susunan defence policy itu didasarkan atas itu. "The enemy is the North, the possible attack of the enemy will come from the North". Djadi, diadjarkan kepada kita, kalau kau mau defence, menghadaplah keutara, djangan ngadap kidul, ngadap ngulon, ngadap ngetan, menghadaplah keutara.'

136 In Doktrin Perdjuangan TNI 'Tri Ubaya Cakti', 2o. 'Djadi Angkatan Bersendjata, perkataan itu adalah closely inhaerent, inhaerent serapatznja dengan musuh. Malahan "doel' dari perang jaitu apa? Bukan sadja mempertahankan diri sendiri. "Doel” daripada perangnja itu, mengalahkan musuh; tidak ada orang mengadakan perang, kalau tidak dengan maksud untuk menghantjurkan, mengalahkan musuh.'

137 Thus, the panutan characters discussed earlier and within the Javanese proverbs: ing ngarsa sung tuladha, ing madya mangun karsa, and tut wuri handayani, extolling the virtues of leadership within the common people, but also more modern ideals of efficiency, transparency, humbleness, and planning capabilities. See Doktrin Perdjuangan TNI-AD. 'Tri Ubaya Cakti'. Buku Induk (Jakarta: Skodik Wala dan Pawamil ABri, 1968), 38.

138 In Doktrin Perdjuangan TNI-AD, 9. 'Orde Baru mengingini suatu tata-fikir jang lebih realistis dan pragmatis, walaupun tidak meninggalkan idealisme perdjuangan.' 
The discussion of the definition of the state enemy in the Seskoad above has already identified the elements that the military wished to control: communists, separatists, federalists, atheists, religious extremists, imperialists, isolationists, liberals, and even cynics. What this meant was that the enemy existed both outside of and within Indonesian society itself. In accordance with the rule book of the Cold War, the government was fighting against ideas and ideologies as well as armed militias and other radicals. The fight was to have a variety of psychological, ideological, and military dimensions. There were two major approaches that the military took with regard to state enemies. The first was the deployment of conventional strike forces against separatists, imperialists and, later on, communists and leftists through the use of military violence. The second was the so-called military Karya programme.

Nasution initially introduced the Karya programme in order to allow the military access to positions and influence in the various sectors of civilian life that had been off-limits before the programme's formal inauguration at the end of the 195os. Another significant reason for the programme was mass population control, especially to protect against communist influence in rural areas. The PKI, with good reason, wanted the army to abandon the territorial doctrine which the Karya programme was partially based upon. Communist support for the Tri Ubaya Cakti doctrine and its legitimation of foreign adventures provided the PKI cadres with relief from the military harassment that was being inflicted on them by the army during the late Guided Democray period. ${ }^{139}$

By the early 196os, several ideologies had effectively been banned in national politics. Liberalism, with its perceived supporters as epitomized by the PSI, was banned. By the late 1950s, Nasution had earnestly begun controlling civil society through the formation of various Military Cooperation Bodies (Badan Kerdjasama Militer, BKs). The BKS mirrored party-based onderbouw organizations, the largest of which were usually communist organizations. The move to integrate civil society organizations first started with veterans through the formation of the Veteran's Legion of the Republic of Indonesia (Legiun Veteran Republik Indonesia, LVRI), a new veteran's organization that was to replace all other veterans' organizations, some of the largest of which were the All-Indonesia Union of Former Fighters (Persatuan Bekas Pedjuang Bersendjata Seluruh Indonesia,

139 Aidit in his many speeches to military personnel in the various officer schools repeatedly stressed the need to abandon the territorial doctrine. Moekmin Hidajat, 'PKI versus Perang Wilajah', $18-23$. 
Perbepsi), associated with the PKI, and the Former Islamic Fighters Union (Bekas Pedjuang Islam Bersendjata), associated with Masjumi. The extensive opposition to this military move resulted in a change of tactics and the setting up of the BKs. The first BKS was the Cooperation Body between Youth and Military (Badan Kerdjasama Pemuda Militer, BKSPM), an organization that used preman youths with a thuggish reputation. As Loren Ryter has shown, the BKSPM was the nucleus of the later powerful Pemuda Pancasila group that existed during the New Order and played an important part in the early years of the regime, including during the $1965^{-1966}$ communist massacres. ${ }^{140}$

Job expansion for army personnel occurred at a variety of levels. At the highest levels were those military officers who were asked to sit in Parliament or to head various ministries, departments, and provinces, or fill other highlevel administrative posts. The expansion of the military territorial district (Kodam) during the Guided Democracy was significant: from seven to sixteen districts. ${ }^{141}$ The root of this expansion was the willingness of the army under Nasution in 1958 to avert a military dictatorship and instead implement a Middle Way (Dwifungsi). This concept, as planned between Sukarno, the cabinet, and the leaders of the armed forces, would give wide-ranging opportunities to military officers on an individual basis, but as exponents of the military they would be able 'to participate in non-military fields and [...] determin[e] national policies of the highest levels including such fields as state finance, economy, and so on'. ${ }^{142}$

The takeover of formerly Dutch-owned businesses resulted in a sudden expansion in the number of managerial posts that required filling, and Indonesia had a hard time finding replacements for these roles. Parliamentary Decree No. II/MPRS/196o is an important document, as it legalized army participation and proposed a fundamentally different economic framework for the country. In $\mathrm{A} / \mathrm{III} / 4 \mathrm{O} / 5$, it stated that 'the Indonesian armed forces and the state police shall participate in the process of production without diminishing their main respective tasks'. In A/III $/ 69 / 415$, it stated that 'the role and activities of the armed forces in the field of production bring them closer to the people more intensively in the process of state development especially in matters of industrialization and the carrying out of land reform.'. ${ }^{43}$ Many of the military men

\footnotetext{
140 Ryter, 'Youth, Gangs and the State in Indonesia', 36 and 82. Many of those in the gangs of the New Order were sons of bureaucrats and army officers, indicating the tight connections that the elites had to various sectors of Indonesian society.

141 Sundhaussen, The Road to Power, 125.

142 Sundhaussen, The Road to Power, 126.

143 Peraturan Pemerintah No. 16 tentang Permintaan dan Pelaksanaan Bantuan Militer.
} 
had some measure of education. The army officer corps represented an especially highly educated group, with 71 per cent having experience of higher education and some having attended management courses in the United States. ${ }^{144}$

As part of the Karya group, the military was entitled to thirty-five seats in Parliament. In practically all newly created institutions of the Guided Democracy, the military was to play a role and hold prominent roles. Military members were appointed as governors and in other executive civil-service positions. In fact, there were more members of the military in important government posts during the final years of the Guided Democracy than in the early years of the New Order. ${ }^{145}$

The territorial-affairs section of the general staff had been developing the regional authority of the military since the proclamation of martial law in 1957. The structure of this authority was commonly known as the Tjatur Tunggal. ${ }^{146}$ At the highest regional (provincial) level, under martial law, the role of the army was supreme within a governmental structure that incorporated other civilian authorities. The Tjatur Tunggal structured regional government in a hierarchy, placing the territorial military commander in charge of a committee that was formed of the civilian governor, the chief of police, and the district attorney. If martial law were to be lifted, the civilian governor would replace the military commander as chairman of the committee. However, when martial law was finally lifted in 1963 , the military regional structure of the Tjatur Tunggal effectively remained in place

The Seskoad further developed the territorial doctrine on the orders of General Nasution. In 1958, Colonel Soewarto, then assistant commander of the Seskoad, was ordered to conduct a series of meetings to define the territorial doctrine. Prior to Sukarno's visit to Washington in April 1961, General Edward Lansdale proposed a Civic Action programme for Indonesia that involved the Indonesian army in rural reconstruction and development projects. ${ }^{147}$ According to Frederick Bunnell, the chief of staff approached US officers in Jakarta in July 1962 for American assistance in Civic Action programmes as one of the

\footnotetext{
144 Roeder, Who's Who in Indonesia, 46o.

145 In September 1962, officers of the Karya operation attended the Graduate School of Business Administration at Harvard University, among others. Laporan Tahunan ${ }_{196}{ }_{3}$ Staf Angkatan Bersendjata, Direktorat Keamanan Dalam Negeri, Territorial dan Perlawanan Rakjat (Jakarta: Direktorat Keamanan Dalam Negeri,Territorial dan Perlawanan Rakjat, 1964), 11-12.

146 Translated as 'Four in One' from Javanese, providing a picture for the structure of regional governments.

147 Simpson, Economists with Guns, 48.
} 
TNI's post-West Papuan military strategies. ${ }^{148}$ In 1963 , the Americans started implementing the Civic Action programme as part of their assistance programme, along with schemes in five other Asia-Pacific countries.

President Kennedy offered the Military Assistance Program (MAP) agreement during President Sukarno's visit to Washington in 1961. In the spring of 1962, army chief of staff General Maxwell Taylor visited Indonesia and concluded a Civic Action agreement at the Indonesian army headquarters. Near the end of the year, an inter-agency Civic Action Advisory Team arrived in Indonesia and established the office of Special Assistant for Civic Action at the US embassy in Jakarta. Colonel George Benson, former military attaché to Indonesia and close friend to many of the Indonesian military elite, became its first special assistant. ${ }^{149}$ By early 1963, American bulldozers, road scrapers, and power hammers were arriving in Indonesia. Fifty US officers from the Fort Belvoir Civic-Action training centre, Virginia, were expected to train Indonesian army engineers on the use of the machinery. A group of Indonesian officers was also sent to army engineering training centres at Fort Belvoir and Fort Leonard Wood, Missouri. General Yani officially opened the Civic Action course in late 1963. Civic Action centres were being opened throughout the archipelago for the purpose of training those in the 'development' brigade. The programme was conceived as counter-insurgency training and the plan was to equip thirtyfive to forty infantry battalions and thirteen engineering battalions. ${ }^{150}$

Under the command of the Siliwangi Division's General Kosasih and, later, General Ibrahim Adjie, ${ }^{151}$ the Bhakti operation was launched specifically to implement the Civic Action programme within former DI areas in West Java. By 1962, the civic mission was absorbing 40 per cent of the army's manpower in rural development projects.

The expansion of Civic Action, and the implementation of the military's Karya role, meant an expansion of military education into sectors previously limited to civilians. ${ }^{152}$ Like the formation of the Civic Action training centres

148 Frederick P. Bunnell, 'The Kennedy Initiatives in Indonesia, 1962-1963', PhD Dissertation Cornell University, Ithaca, 1969, 147; Mrazek, The United States and the Indonesian Military, 78 .

149 Mrazek, The United States and the Indonesian Military, 77; Brian Evans III, 'The Influence of the United States Army on the Development of the Indonesian Army, 1954-1964', Indonesia, 47 (April 1989), 25-48.

150 Bunnell, 'The Kennedy Initiatives', 148.

151 Nasution, Memenuhi Panggilan Tugas, Jilid v, 182.

$15^{2}$ For instance, the production of rice, in which the military increasingly played a part through the People's Welfare Operation Command (Komando Operasi Gerakan Makmur, KOGM), created in 1959. The effort to achieve sustainability in rice production was thus made within military-style organizations or commands, in which the military had an 
above, some educational institutes were created specifically for military training in civilian fields. They focused on the development of the military's engineering capabilities in building roads and other infrastructural projects, similar to the American Military Engineering Corps. Special managerial courses for military students were held at various universities, including a course in administration science at the Faculty of Social and Political Science at Padjadaran University in Bandung. Padjadjaran social scientists regularly lectured at the Seskoad and army officers could complete degree courses there. Ahmad Yani said: 'We know for certain that the development of our country should be in the hands of the experts and those responsible. This requires technical education in all fields. Administrative science involving managerial know-how is one of the most important sciences, because administrative capabilities determine the smoothness of our efforts and increase efficiency.'153

Even when US aid to Indonesia was significantly reduced in 1964, and was expected to be stopped in 1965 , the amount of money going into the MAP was actually increasing. Between 1962 and $1965, \$ 39.5$ million of US aid was given to the MAP in comparison to the $\$ 28.3$ million of US aid that had been disbursed between 1949 and 1961. In fact, military aid for the Civic Action programme was increased in 1965 , when many thought that the United States had stopped all aid. As early as May 1965, US military suppliers were negotiating equipment sales to Indonesia. In July 1965, Rockwell-Standard delivered two hundred light aircraft for the army as part of the Civic Action programme. ${ }^{154}$

Suwarto, in an article co-written with UI economist Kartomo Wirosuhardjo, laid bare the importance of territorial development and the Civic Action programme. The rationale for Civic Action from a military standpoint was obviously security, yet the goal of the programme was in line with the constitution: the creation of a peaceful, wealthy, and just society. In order to reach that

important role, together with the agricultural ministry and the Depernas. The production of rice was coordinated with the Food Source Board (Dewan Bahan Makanan) and the various Tjatur Tunggal at the provincial level, thus securing a truly state-controlled food production institution. The military was an essential component in this command structure.

153 Ahmad Yani, TNI Membina Revolusi (Jakarta: Delegasi, 1964), 112. Yani, in a speech titled 'Beladjar dengan Tekun dan Penuh Kesadaran' at the Social and Political Faculty, Padjadjaran University. 'Kita mengetahui dengan pasti bahwa pembangunan Negara kita ini hendaknjalah berada didalam tangan para achli dan jang bertanggung-djawab. Untuk itu diperlukan pendidikan kedjuruan dalam segala bidang. Kedjuruan administrasi jang meliputi managerial Know how adalah salah satu kedjuruan jang sangat penting, karena keberesan administrasi akan membantu melantjarkan setiap usaha kita dan meninggikan efficientie.'

154 Scott, 'The United States and the Overthrow of Sukarno', 239-64. 
goal, the military would have to do its part in directing social change. Thus, Civic Action implied bringing about modernization by channelling villagers toward other modes of social, political, and cultural being than the ones offered by political parties, in particular the communists. In the words of Suwarto and Kartomo: 'By introducing the spirit of gotong royong, ${ }^{155}$ which is one of the principles of Indonesian socialism, Civic Action will already have helped in moving Indonesian socialism forward.'156

This was a result of the changing attitude the army had to security. According to Soewarto, 'in the Cold War there is no difference between peace and war, ${ }^{\prime}{ }^{157}$ a statement that implied the need to build a doctrine that would function during both war and peacetime. Like the BKS organizations, the purpose of Civic Action was population control. In accordance with the Seskoad's classification of the potential enemies of the state, the uneducated and simple peasants could potentially have been attracted to communist ideas. The army's anti-communist campaign was thus achieved through the dissemination of material incentives; that is, through military-sponsored economic development. Suwarto and Kartomo imagined a rurally based army with military barracks built throughout the rural heartlands.

For the army, the introduction of army personnel to manual work provided them with abilities that would help them transition to a future civilian life. In an article in Karya Wira Djati, Soewarto noted that army personnel must learn to become community leaders. It thus asked the individual soldier to develop his social skills. ${ }^{158}$

It was hoped that developing the rural areas would lessen the perceived jealousy of villagers towards the cities. In fact, the main security threat perceived by the army was rural poverty. Development was an essential component of the protection of the national and urban elite from the threat of a communist

155 Gotong royong (or rojong) means mutual assistance, it also denotes a political discourse on authority in Indonesian in the tradition of the familial state.

156 Suwarto and Kartomo Wirosuhardjo, 'Bantuan Angkatan Perang dalam Pembangunan Suatu Persiapan Pembinaan Wilajah', in Suwarto, Himpunan Karangan Letnan Djenderal Anumerta Suwarto (Jakarta: Karya Wira Jati, 1967), 57. 'Jang terpenting ialah adanja kesadaran bahwa perbaikan desa mungkin ditjapai dan telah ditjapai dengan gotong royong. Dengan kembalinja semangat gotong rojong jang merupakan salah satu sendi dari Sosialisme Indonesia, civic action ikut membantu langsung pelaksanaan Sosialisme Indonesia.'

157 Suwarto, 'Tjeramah tentang Perang Wilajah', in Suwarto, Himpunan Karangan Letnan Djenderal Anumerta Suwarto (Jakarta: Karya Wira Jati, 1967), 25. The full sentence was: 'Djadi oleh karena dalam cold war ini pada hakekatnja tidak ada perbedaan antara perang dan damai dikatakan bahwa war is never our goal.'

158 Suwarto, 'Civic Action', Karya Wira Djati, 2/8 (1962). 
insurrection. Kartomo's idea, which has been elaborated above, of a militaryexpert-business tripartite ruling class is a continuation of this idea. Thus, mass control was not merely conceived through the lens of a projection of violent power, but also as a projection of modernity. ${ }^{159}$ It was an attempt to turn soldiers into social engineers. ${ }^{160}$

12

Conclusion

The relationships between social scientists, military officers, and managers developed during this period. Military officers routinely undertook economic research and many, like Nasution and Adjie, published articles in professional managerial magazines. It is also no coincidence that those officers with managerial careers were the ones who supported the territorial doctrine. The territorial doctrine legitimated their participation in the management of Indonesian public life and the country's economy. As a result, civilian experts and territorial officers had the same affinities, as both were managers. It was because of this that they maintained a strong connection and, perhaps, even a feeling of esprit de corps. Soehardiman credited Suharto's success 'especially to his capable managerial skills'. ${ }^{161}$ This says a lot about his position as a military manager, but it also leads us to the view of many from within the New Order: its success was the result of the application of the managerial ideology that had become available and was taught to many military officers during the period. The growing relationship between the military and both social science and social scientists strengthens the view that this was not merely a momentary strategic decision but a basic strategy of the New Order state and the modernist view it had of itself, which included its rational and scientific foundation and its managerial capabilities.

\footnotetext{
159 Latham, The Right Kind of Revolution, 123-4.

16o Andrew J. Birtle, U.S. Army Counterinsurgency and Contingency Operations Doctrine, 19421976 (Washington: Center of Military History, 2006), 225; Suwarto and Kartomo, 'Bantuan Angkatan Perang', 56-7.

161 Soehardiman, Kupersembahkan kepada Pengadilan Sejarah, 223.
} 